\title{
はりを用いたねじ締結体の内力係数に関する研究*
}

\author{
清 水 秀 治*1, 片 岡 真 澄*1 \\ 船 見 国 男*1, 植 草 昌 彦*1
}

\section{Study on Force Ratio of Bolted Joints Using Beam}

\author{
Hideharu SHIMIZU*2, Masumi KATAOKA, \\ Kunio FUNAMI and Masahiko UEKUSA \\ ${ }^{* 2}$ Chiba Institute of Technology, Dept. of Mechanical Engineering, \\ Tsudanuma 2-17*1, Narashino, Chiba, 275-0016 Japan
}

\begin{abstract}
In the case of fixing the tower crane on the base at the building site, the fastening method where the frame is held down by a beam called "Kanzashi" and bolts are inserted in it is widely used. This "Kanzashi" often deflects because of insufficient rigidity when bolts are fastened. This paper describes the results of an experiment employed a crane frame model, derivation of a practical formula based on strength of materials and comparisons of the theoretical and experimental values. The results obtained are that the force ratio became smaller and the bending force ratio became larger with decreasing the thickness or increasing the bolted distance. The theoretical values agreed well with the experimental values.
\end{abstract}

Key Words: Force Ratio, Load Factor, Bolted Joints, Beam, Kanzashi, Structural Analysis

\section{1. 緒言}

ビルの建築現場におけるタワークレーンの設置で は，接合するクレーン脚部と架台部双方に穴をあけ 「かんざし」と呼ばれるはりをそれぞれに貫通させ， これをボルト締結する方法がある。この方法は，一般 的に用いられているフランジ接合のように密着させた 接合面をボルト締めするのとは異なり，接合部から突 出したはりの部分をボルトで締結するため，被締付け 物であるボルト軸線上のはりは面どうしが密着しな い.このためボルトを締付けるとはりにたわみが生 じ，必然的にボルトが㳉曲する。またこのような締結 体に外力が作用するとボルトには追加軸力に加えて, 追加曲げ応力が生ずることになる。

ところで、ボルト締結体に外力が作用するとき，ボ ルトに生ずる追加軸力と外力の比である内力係数はボ ルト締結体設計上重要な因子とされ、フランジを用い た締結体については，それらに関する多くの研究(1)が なされている。しかし被締付け物がたわみ，ボルトが 湾曲するような場合の内力係数を調べた研究は少な

\footnotetext{
* 原稿受付 1999 年 1 月 21 日

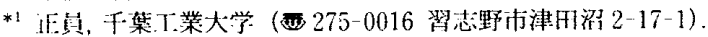

E mail : P01simiz@pf.it-chiba.ac.jp
}

く，また追加曲げ応力等を調べた報告例は見当たらな いようである。

そこで本研究では，はりを用いた接合体に外力が作 用する場合をとりあげ，はりの剛性等の相違がボルト に作用する追加軸力や追加曲げ応力に及ほす影響を調 ベた。また追加曲げ応力を評価するため, 内力係数に

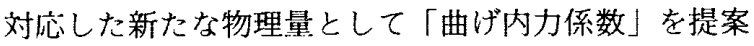
した。理論解析では，フランジ締結体の解析に従来用 いられている手法(2) (4) と, これを一部修正した手法 を用いて上述の諸係数を求めるための簡便な式を導出 した。そしてこれら 2 手法から得られた理論値と実験 值等を比較することから，これらの式の有効性も検討 した。

\section{2. 実 験}

実物のクレーン脚部は矩形断面をしたフレームで, 本体と一体に加上されており，それらは本体から放射 状に 3 本張り出していることが一般的である。しかし 本報では簡単のため 1 本の脚部とその据付架台一組を 本体から切り離しモデル化した。実験に使用したモデ ルを図 1 に示す。このモデルは脚部と架台を同形と し，万能材料試験機で引張荷重が急荷できるよう実物 の $1 / 12$ 程度の寸法にしたものである.ボルトは 
M 20,ピッチ 2.5 のスタッドボルトを使用した。また はりは，ボルト締結時のたわみ状態が変化するように 板厚および長さの異なる 6 種類を準倩した。図 2 およ び表 1 に締結体，ボルトおよびはりの寸法を示す。な お，脚部，架台，はりおよびボルトの材質はS 45 Cで あり，それらすべてについて塑性変形を防ぐため引張 強さが $1200 \mathrm{MPa}$ 位になるよう熱処理を施した。ま た脚部抢よび架台のはりを槓通させるための穴寸法 は，はりのたわみが拘束されることのないように縦方 向 $35 \mathrm{~mm}$, 横方向 $46 \mathrm{~mm}$ とした。またボルト穴径は JIS 1 級の $\phi 21$ とした。ボルトの軸力および曲げ応 測定のため，闻ボルトの中央円周上長手力向にひずみ ダージを 4 枚はり，またはりにも追加曲げモーメント の值を確認するためひずみゲージをはった。ボルトを 任意の締付け力で締付けた後, 万能材料試験機で荷重 を負荷し, 各荷重における応力および軸力を求めた。

\section{3. 理論}

$3 \cdot 1$ 各種内力係数の定義 図 1 において, 架台 に外力 $2 W$ が作用亦るとはりがたわむため、ボルトに は追加唓少 $F_{a \ell}$ と追加曲げモーメント $M_{a b}$ が作用し， ボルトに生ずる最大応力增加分 $\sigma_{a \max }$ は

$$
\sigma_{a \max }=\frac{F_{a t}}{A_{b}}+\frac{M_{a \dot{b}}}{Z_{b}}
$$

ただし

Table 1 Dimensions of beam

\begin{tabular}{c|c|c|c}
\hline ModeI & $t(\mathrm{~mm})$ & $I_{k,}(\mathrm{~mm})$ & $I_{o}(\mathrm{~mm})$ \\
\hline$t 20160$ & 20 & 60 & 7.87 \\
\hline$t 25160$ & 25 & 60 & 4.15 \\
\hline$t 30160$ & 30 & 60 & 23.6 \\
\hline$t 20130$ & 20 & 30 & 3.53 \\
\hline$t 25130$ & 25 & 30 & 1.81 \\
\hline$t 30130$ & 30 & 30 & 1.02 \\
\hline
\end{tabular}

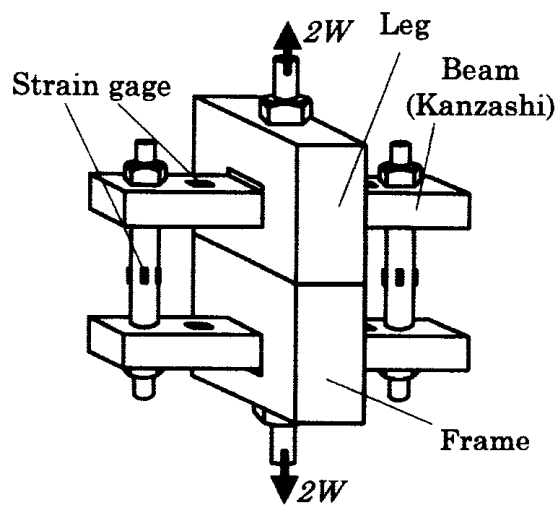

Fig. I Schematic representation of "Kanzashi" model

\section{$A_{b}:$ ボルト軸部の断面積}

$Z_{b}:$ ボルト軸部の断面係数

また式（1）の両辺にボルト軸部の断面積 $A_{b}$ を乗じ たのち外力 $W$ で除すことから

$$
\frac{\sigma_{a \max } \times A_{b}}{W}=\frac{F_{a t}}{W}+\frac{M_{a b}}{Z_{b}} \cdot \frac{A_{b}}{W}
$$

ここで式 (2)右辺第 1 項はいわゆる内力係数である からこれを $\phi_{e}$ ，また第 2 項を内力係数に刘伈させて 曲げ內力係数 $\phi_{b e n}$ と定義し, 追加曲げ応力を栖価す るための物理量とする。一方左辺の $\sigma_{a \max } \times A_{b}$ は最 大軸力增加分であるからこれを $W て ゙$ て除した物理量 在最大内力係数 $\phi_{\max }$ と定義すると

$\phi_{\max }=\phi_{e}+\phi_{\text {ben }}$.

$3 \cdot 2$ 従来の手法を用いた $\phi_{e}, \phi_{b e n}$ の導出 式 (3)0 $\phi_{e}$, $\phi_{b e n}$ を求めるためには追加軸力 $F_{a t}$ と追 加曲げモーメント $M_{a b}$ を知る必要がある。従来フラ ンジ継手のように被締付け部材どうしが密着している
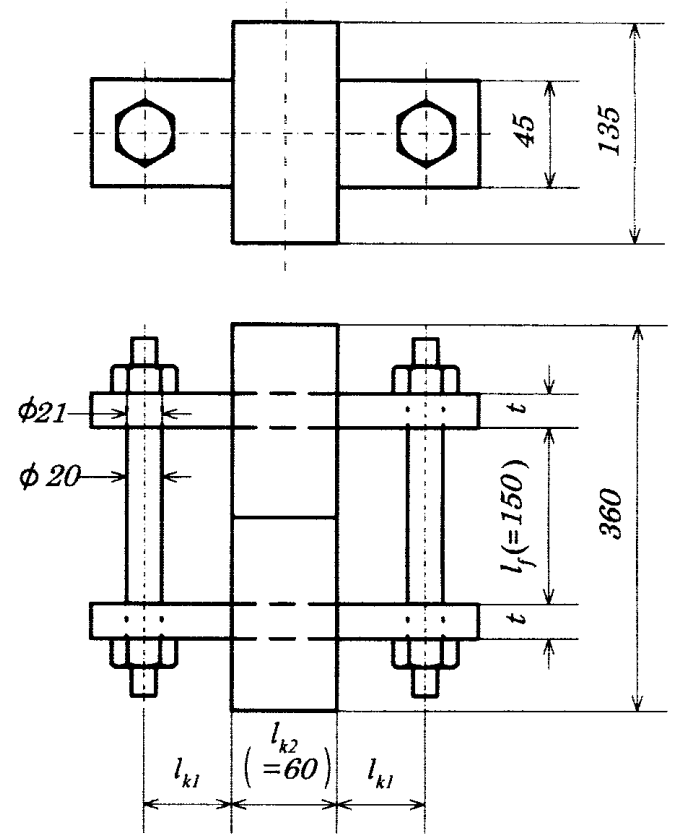

(a) Bolted joint

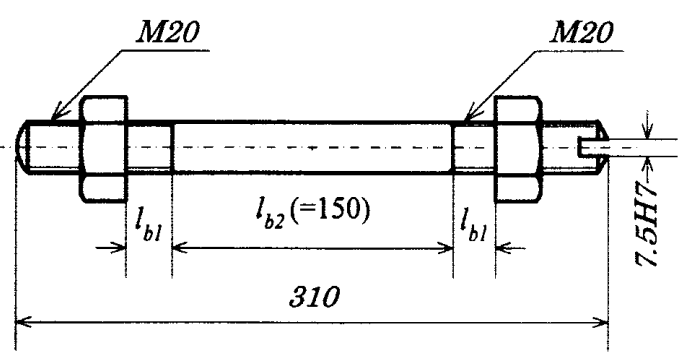

(b) Stud bolt

Fig. 2 Shape and dimensions of bolted joints and specimen 
場合，すなわちナット座面部と被締付け部材も全面で 接触している締結体に作用する追加軸力 $F_{a t}$ は,ナッ ト座面部とボルト軸線の交点(以下では釣合い点と呼 ぶに抢けるボルト長手方向の変位の釣合いより，ま たボルトに発生する曲げモーメント $M_{a b}$ は,この釣 合い点に扔けるボルトと被締付け物のたわみ角を等値 することから求めている(2)(3). そこで本モデルにもこ の手法(以下では従来の手法と呼ぶ)の適用を試みる. したがって,ここでははりの剛性によらず,ナット座 面部とはりは密着しているものと仮定することにな る.

図 3(a) は任意の締付け力で左右のボルトを対称に 締付けた締結体の架台部に $2 W$ の引張外力を負荷し た場合の模式図である。このときボルト 1 本当たりに

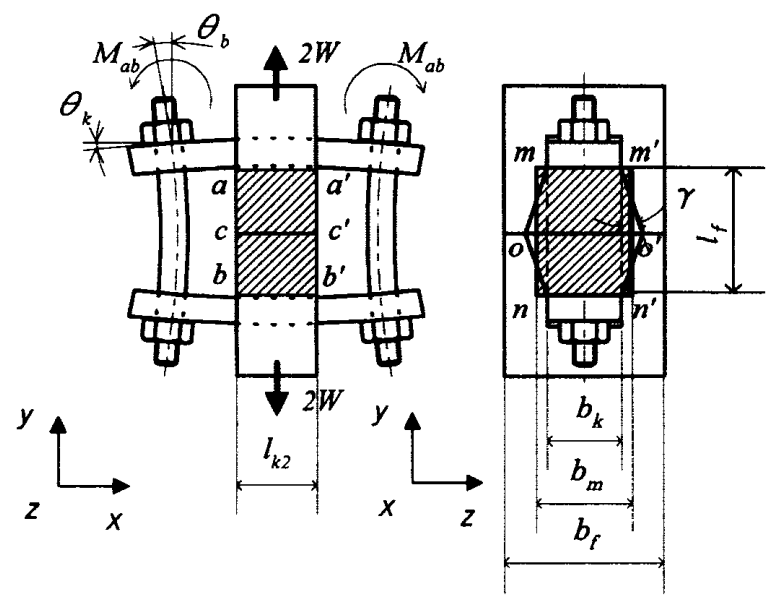

(a) Bolted joint

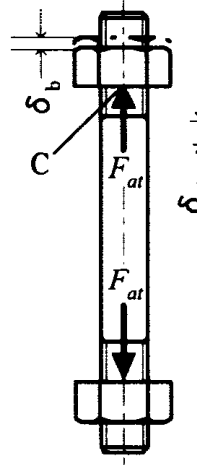

(b) Bolt $\cdot$ nut system

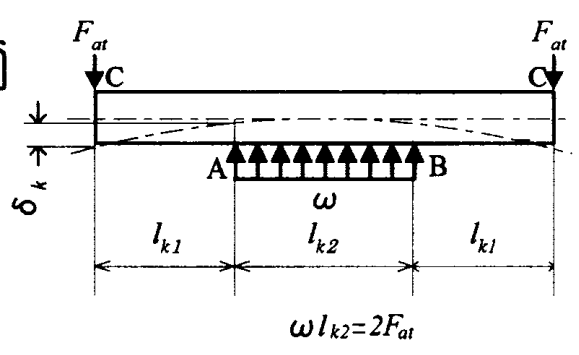

(c) Beam

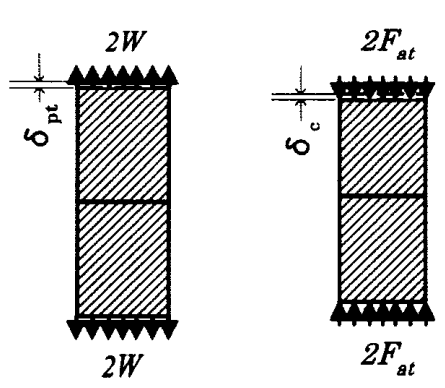

(d) Frame (leg)

Fig. 3 Model to find force ratio
生ずる追加軸力 $F_{a t}$ によって生ずるボルトの伸びを $\delta_{b}\left[\right.$ 図 3(b)], 釣合い点すなわち C 点における $F_{a t}$ の反力によるはりのたわみを $\delta_{k}$ [図3(c)における $\mathrm{A}$ 点と $\mathrm{C}$ 点の相対たわみ量], また架台部の外力 $2 W$ による伸びを $\delta_{p t}$, 反力 $2 F_{a t}$ による縮み量を $\delta_{c}$ [図 3(d)] とすると

$$
\delta_{b}=\delta_{p t}-\left(\delta_{c}+2 \delta_{k}\right)
$$

ここで,ボルトおよびはりのばね定数を $C_{b}, C_{k}$ と し, 架台部の引張り, 圧縮のばね定数をそれぞれ $C_{p t}$, $C_{p c}$ と扔き以下で用いる記号を

\section{$d:$ ボルト軸部直径}

$d_{A}:$ ねじ部有効径

$E_{b}:$ ボルトの絴弾性係数

$E_{k}:$ はりの縦弾性係数

$E_{f}:$ 架台の縦弾性係数

$I_{b 1}$ : ボルトねじ部の断面二次モーメント(有効径)

$I_{b 2}$ : ボルト軸部の断面二次モーメント

$I_{k}$ :はりの断面二次モーメント

とすると式(4)は

$$
\frac{F_{a t}}{C_{b}}=\frac{2 W}{C_{p t}}-\left(\frac{2 F_{a t}}{C_{p c}}+\frac{2 F_{a t}}{C_{k}}\right)
$$

となり,これより

$$
F_{a t}=\frac{W}{C_{p t}} \cdot \frac{1}{1 /\left(2 C_{b}\right)+1 / C_{p c}+1 / C_{k}}
$$

ここで $C_{b}$ は, 文献 (2)等に示されている周知のボ ルトのばね定数式を本モデルを用いているスタッドボ ルト [図 2(b)] 用に変形することから

$$
C_{b}=\frac{E_{b}}{4 l_{b 2} /\left(\pi d^{2}\right)+8\left(l_{b 1}+0.7 d\right) /\left(\pi d_{A}^{2}\right)}
$$

次に $C_{k}$ を決定する。図 3(c) は集中荷重 $F_{a t}$ が作 用するはりの状態を示したもので，はりと架台の接触 部分 (区間 $l_{k 2}$ 部分) は，はりがたわむため，中央に近 づくほど荷重の小さくなるアーチ形の荷重分布と考え られるが,ここでは簡略化のため等分布荷重と仮定し た。また同様の理由によりボルト穴も無視した。した がってはりのばね定数 $C_{k}$ は雨端支持はりとしての C 点と $\mathrm{A}$ 点の相対たわみ量から

$$
C_{k}=\frac{12 E_{k} I_{k}}{l_{k 1}\left(4 l_{k 1}^{2}+6 l_{k 1} l_{k 2}+l_{k 2}^{2}\right)}
$$

$C_{p t}, C_{p c}$ の導出にあたっては, 締付け物であるはりの 幅 $b_{k}$ に比べて被締付け物である架台部の幅 $b_{f}$ が大 きいことから架台部における応力分布を以下のように 補正した。すなわち本報ではフリッチェらが提案して いる影響円すい(5) の代わりに図 3(a)に示すような二 つの台形柱(台形 moo'm' と矩形 acc'a' で形成される 立体およびnoo'n'と bcc'b'で形成される立体)を考 え，応力はこの二つの台形柱と等価な四角柱(ハッチ 
ング部分)内に分乕するものとした。これより等価四 角柱の断面積 $A_{\mathrm{eq}}$ は

$$
A_{\text {eq }}=l_{k 2}\left\{b_{k}+\left(l_{f} \cdot \tan \gamma\right) / 2\right\}
$$

となり

$$
C_{p c}=\frac{A_{\mathrm{eq}} \cdot E_{f}}{l_{f}}=\frac{l_{k 2}\left\{b_{k}+\left(l_{f} \cdot \tan \gamma\right) / 2\right\} E_{j}}{l_{f}}
$$

ただし $\gamma$ は影響円すいの半頂角に相当する角度で ある.ここで $C_{p t}=C_{p c}$ と仮定することから， $\gamma$ の值 を与えれば式 $(5) \sim(7)$, 式 (9)より $F_{a t}$ が決定さ れ， $\phi_{e}$ が求まることになる。そこで, $\gamma$ の值はフリッ チェの提案する $\gamma \fallingdotseq 11^{\circ} 20^{\prime}$ を採用した(5). 次にボル卜 に作用する曲げモーメント $M_{a b}$ は釣合い点に打ける ボルトとはりのたわみ角を等値することから求まる。 図3(a)のように曲げモーメント $M_{a b}$ による゙ルト のたわみ角 $\theta_{0}$ は

$$
\theta_{b}=\frac{M_{a b}}{E_{b}}\left(\frac{l_{b 1}}{I_{b 1}}+\frac{l_{b 2}}{2 I_{b 2}}\right)
$$

またはりのなわみ角 $\theta_{k}$ は

$$
\theta_{k}=\frac{F_{a t}}{12 E_{k} I_{k}}\left(l_{k 2}^{2}+6 l_{k 1}^{2}+6 l_{k 1} \cdot l_{k 2}\right)
$$

式(10)，(11)のたわみ角を等しいと扔くことから

$$
M_{a b}=\frac{F_{a t} \cdot E_{b}}{12 E_{k} I_{k}} \cdot \frac{\left(l_{k 2}^{2}+6 l_{k 1}^{2}+6 l_{k 1} \cdot l_{k 2}\right)}{\left\{l_{b 1} / I_{b 1}+l_{b 2} /\left(2 I_{b 2}\right)\right\}}
$$

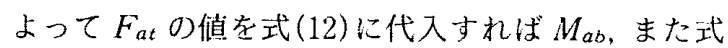
(2)の右辺第 2 項より $\phi_{\text {ben }}$ が決定できる.

$\mathbf{3} \cdot 3$ 修正した手法による $\phi_{e}, \phi_{b e n}$ の導出 $3 \cdot 2$ 節では，ナット座面部とはりが全面で接触すると仮尘 し, 釣合い点, すなわち $F_{a t}, M_{a b}$ を求めるために, ボ ルトとはりのたおみおよびたわみ角を等值する点をボ ルト軸線上のC点に定めた。しかし，本研究のはりを 用いた締結体では，ナット座面部とはりの接触状態が 図 4(a)，(b)に示すようにはりの剛性の違いにより 異なると考えられる。すなわち（a）ははりの剛性が大 きい場合で,ナット座面部とはりは全面接触すると考 えられる。一方( b ) は既性が小さい場合でC点にお けるナット座面部とはりは尔離しており，この分離の

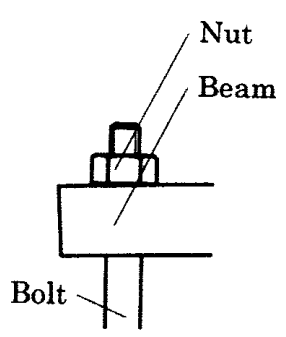

(a) Surface contact

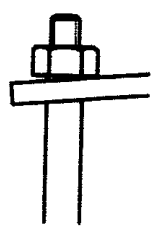

(b) Partial contact
Fig. 4 State of contact
程度は，はりの㧩性が小さいほど大になると考えられ る。そこで以下では実際に接触している位置を考慮 し，釣合い点の修正を試みる。

闵5(a)に示すようにC点より $l_{g}$ 離れたナット座 面部の位置 $\mathrm{G}$ (ナット坐面部とはりの接触区間に作用 与る分布荷重の重心点を通る位置)に追加軸力 $F_{a t}$ が 集中荷重として作用ずるものと仮定し，釣合い点をこ のG点に定める。これによりボルトには追加曲げモ ーメント

$$
M_{a b}=F_{a t} \times l_{g}
$$

が作用することになり，G点でのボルトりたわみ角 $\theta_{b}$ は

$$
\theta_{b}=\frac{F_{a t} l_{g}}{E_{b}}\left(\frac{l_{b 1}}{I_{b 1}}+\frac{l_{b 2}}{2 I_{b 2}}\right)
$$

一方図 $5(\mathrm{~b})$ は追加軸力 $F_{a t}$ の反力が $\mathrm{G}$ 点に作用 しているはりの状態を示したもので(先と同様に $l_{k 2}$ 部分に作用する荷重㹥等分布荷重と仮定) $\mathrm{G}$ 点に打け るたわみ角 $\theta_{k}$ は

$$
\theta_{k}=\frac{F_{a t}}{12 E_{k} I_{k}}\left\{l_{k 2}^{2}+6\left(l_{k 1}-l_{g}\right)^{2}+6\left(l_{k 1}-l_{g}\right) l_{k 2}\right\}
$$

$$
\begin{aligned}
& \text { ここで } \theta_{b}=\theta_{k} \text { とおくことから } \\
& l_{g}^{2}-\left\{l_{k 2}+2 l_{k 1}+\frac{2 E_{k} I_{k}}{E_{b}}\left(\frac{l_{b 1}}{I_{b 1}}+\frac{l_{b 2}}{2 I_{b 2}}\right)\right\} l_{g} \\
& \quad+\frac{l_{k 2}^{2}}{6}+l_{k 1} \cdot l_{k 2}+l_{k 1}^{2}=0 \ldots \ldots \ldots \ldots \ldots \ldots \ldots \ldots \ldots \ldots \ldots \ldots
\end{aligned}
$$

となり，これを解くことから $l_{g}$ が簡単に定まる.

次に $F_{a t}$ は $\mathrm{G}$ 点でのボルト長手方向変位の釣合い 加ら求女られ，その導出過程は従来の手法と同様に行 えばよい.すなおち釣合い点を $\mathrm{G}$ 点に移したことに よる式(4)の修正式は

$$
\delta_{b}+2 l_{g} \tan \theta_{b}=\hat{o}_{p t}-\left(\delta_{c}+2 \delta_{k}\right)
$$

ここで $\tan \theta_{b} \fallingdotseq \theta_{b}$ とし, 式(16)，(17)加式(5)の修 正式は

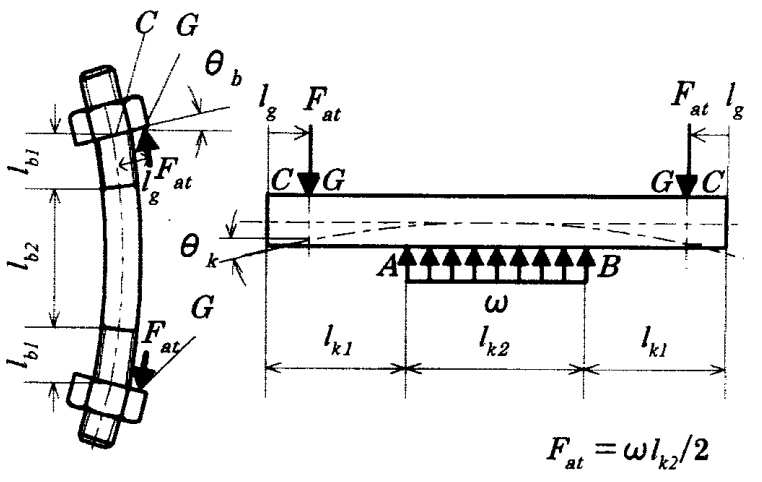

(a) Slope of bolt (b) Slope of Kanzashi

Fig. 5 Model to find $l_{g}$ value 


$$
F_{a t}=\frac{W}{C_{p t}} \cdot \frac{1}{1 /\left(2 C_{b}\right)+1 / C_{p c}+1 / C_{k}^{\prime}+1 / C_{l g}}
$$

となる。ただし $C_{i g}$ は，釣合い点の移動により生じた ボルトの修正ばね定数で

$$
C_{l g}=\frac{E_{b}}{l_{g}^{2}\left\{l_{b 1} / I_{b 1}+l_{b 2} /\left(2 I_{b 2}\right)\right\}}
$$

また $C_{k}^{\prime}$ は式(7)の $l_{k 1}$ を $l_{k 1}-l_{g}$ に置き換えたもので

$$
C_{k}^{\prime}=\frac{12 E_{k} I_{k}}{\left(l_{k 1}-l_{g}\right)\left\{4\left(l_{k 1}-l_{g}\right)^{2}+6\left(l_{k 1}-l_{g}\right) l_{k 2}+l_{k 2}^{2}\right\}}
$$

なお、ここでは $M_{a b}$ を求めるための釣合い点を集 中荷重 $F_{a t}$ が作用する $\mathrm{G}$ 点に定めたが，この仮定の 妥当性の検討と 3.2 節の $C_{k}$ 導出過程で省略したボル 卜穴,およびナット幅に対するはりの幅の影響を調べ るため, 初期締付け力を零とした簡単な有限要素法解 析を行った。図 6 は解析モデルの一例で要素分割を簡 単にするためナット，ボルト軸部断面抢よびボルト穴 の形状は正方形とし，系は左右，上下対称であること から $1 / 8$ モデルとした。使用した解析ソフトはプリプ

Table 2 Dimensions of analysis model

\begin{tabular}{c|c|c|c|c}
\hline Model & $t$ & $I_{k 1}$ & $b_{k} / 2$ & $b_{k} / 2$ \\
\hline$b 206018$ & 20 & 90 & 18 & 18 \\
\hline$b 256018$ & 25 & 90 & 18 & 18 \\
\hline$b 306018$ & 30 & 90 & 18 & 18 \\
\hline$b 206026$ & 20 & 90 & 18 & 26 \\
\hline$b 206036$ & 20 & 90 & 18 & 36 \\
\hline
\end{tabular}
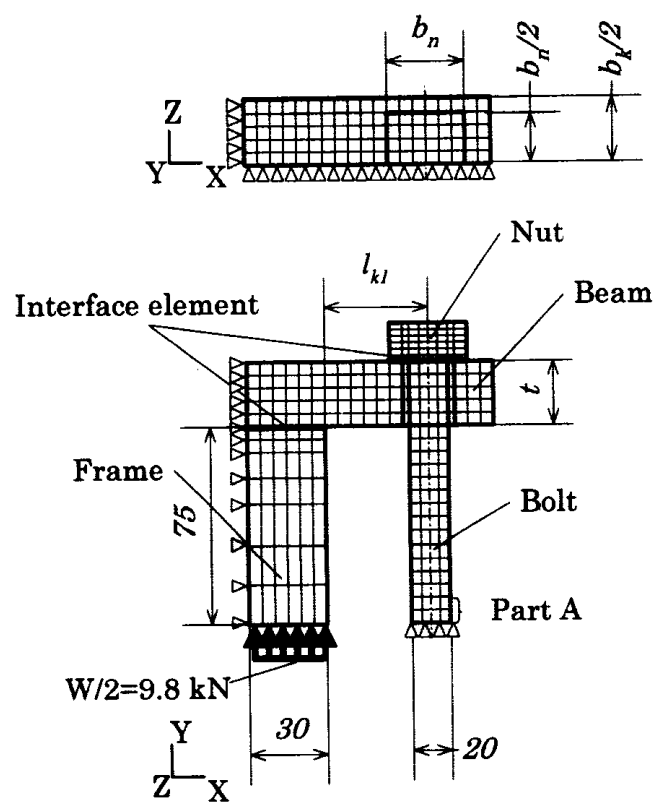

Fig. 6 FEM analysis model to find bending moment
ロセッサ MSC/PATRAN 解析プログラム(ADVAN. CEDFEA)で要素形状は 8 節点六面体要素とし, 要素 数 2 975〜6548 の三次元解析を行った。ナットとはり およびはりと架台の接合面には外力が作用したとき， 分離が生じることを想定し接合要索を插入し摩擦係数 は 0.2 とした。また，ボルト，はり，架台部は同一材 料とし, 用いた縦弾性係数 $E=206 \mathrm{GPa}$, ポアソン比 $\nu=0.3$ ，はりの寸法は表 2 に示す 5 通りとした．表中 の $b_{n}$ はナット幅， $b_{k}$ ははりの幅である.ボルト，ナ ットの断面形状は $20 \mathrm{~mm}, 36 \mathrm{~mm}$ の角，ボルト穴は $24 \mathrm{~mm}$ の正方形で,これらの值は一定とした。

図 7 は外力 $9.8 \mathrm{kN}$ を負荷した場合のボルトに生ず る曲げモーメントの理論值と FEM 解析值の比較であ る、FEM 解析值はボルト表面に生ずる曲げ応力より 換算した。理論值 1 (実線) は従来の手法すなわち式 （12）上り求めた值であり，理論值 2(破線)は修正した 手法，すなわ方式(13)，(16)より求めた理論值で，こ れらの值は，初期締付け力が零であることから $F_{a t}=$ $W(19.6 \mathrm{kN})$ とし，はりのボルト穴を無視した場合の ものである。一方，理論値 3(一点鎖線) は図 8 に示す

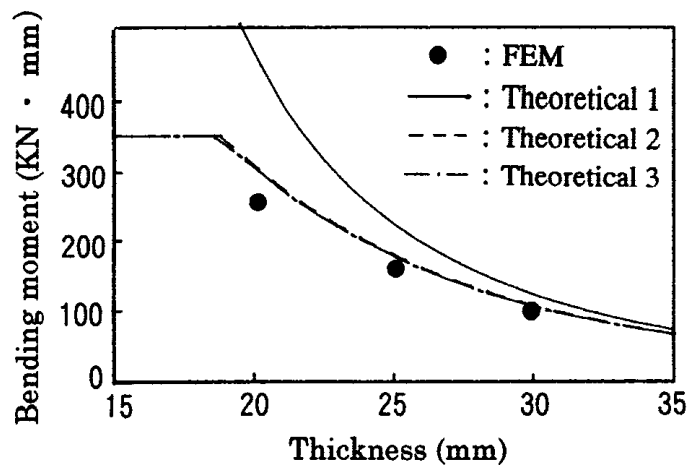

(a) Relationship between thickness of beam and bending moment

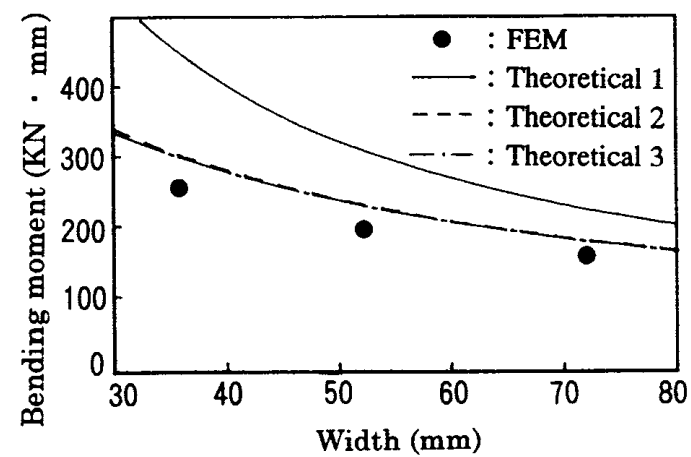

(b) Relationship between width of beam and bending moment

Fig. 7 Comparisons of theoretical values and FEM analysis values of bending moment 
ようにはりのボルト穴 $(24 \mathrm{~mm}$ の正方形)を考虑した 場合の修汭した手法により求めた值である。このはり は断面形状の変化するはりとなるから $\mathrm{G}$ 点における たわみ角 $\theta_{k}$ は次式となる。

$$
\begin{aligned}
\theta_{k} & =\frac{F}{12 E_{k} I_{k}}\left\{l_{k 2}^{2}+6\left(l_{k 1}-l_{g}\right)^{2}+6\left(l_{k 1}-l_{g}\right) l_{k 2}\right. \\
& \left.-6\left(l_{k 0}-l_{g}\right)^{2}\right\}+\frac{W}{2 E_{k} I_{k 0}}\left(l_{k 0}-l_{g}\right)^{2} \cdots \cdots \cdots(21)
\end{aligned}
$$

ここで $I_{k 0}, I_{k}$ ははりの穴のある部分 $\left(\mathrm{AC}^{\prime}\right.$ 間また は $\mathrm{BC}^{\prime}$ 間)，分のない部分 $(\mathrm{AB}$ 間) の断面二次モーメ ントである(図 8 参照)。

図7(a)は，はりの幅とナットの幅を同一寸法(36

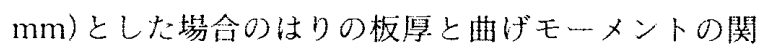
係宗したものであり，図7(b)は，はりの板学 20 $\mathrm{mm}$, ナット幅 $36 \mathrm{~mm}$ とした場合のはりの板幅と曲 げモーメントの関係を調べたものである。また，戍 $7($ a)において板夏約 $19 \mathrm{~mm}$ 以下の範囲で理論值 2, 3 の曲げモーメントが一定となっているが,この籁四 では $l_{g}$ の值がナット幅 $b_{n}$ (図 6 参照)の $1 / 2$ を超える ことから， $l_{g}=b_{n} / 2$ としているためである。

図7よりはりの板厚やナット幅に対してはりの板幅 を変化させた場合に抢いても，理論值 2,3 は FEM 解 析值とよく一致している。また理論值 1 は板将，板幅 が大になるほど，古なわちははりの曲げ剛性が大にな るほど FEM 值や理論值 2,3 に近づくことがわかる。 これより曲げモーメントを求めるための釣含い点は， はりの曲げ風性の大小によらず集中荷重 $F_{a t}$ が作朋 するG器に定めたほうが良いことがわかる。また理

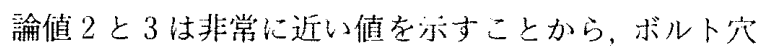

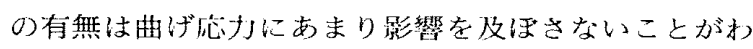
かる。

\section{4. 結果および考察}

$4 \cdot 1$ 内力係数の理論値と実験值の比較 図 9 は

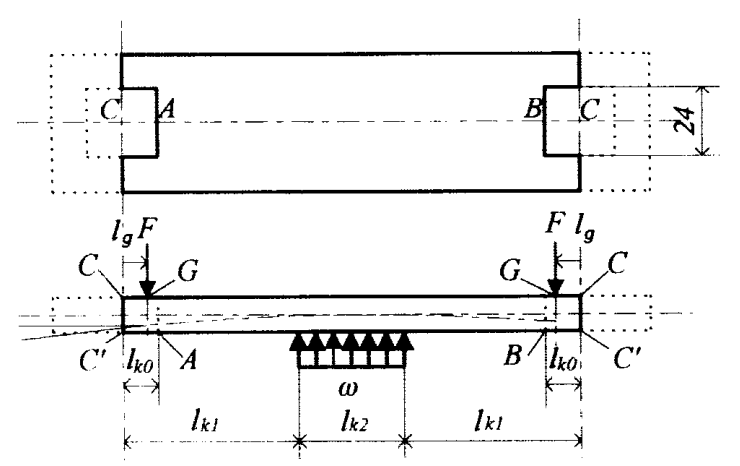

Fig. 8 Shape of beam when conseidering bolt hole
各種はりの内力係数の理論值と実験値の比較を示した もので(a)は $l_{k 1}=60 \mathrm{~mm}$ （b ) は $l_{k 1}=30 \mathrm{~mm}$ の結果 である，図中の理論値 1(実線)は従来の手法，すなわ ち式(2)，(3)，(5)，(12)により求めた值, 理論值 2(破線)は修正した手法，すなわち式（2），(3)，(13)， (16)より求めたものである。また○印は内力係数, 印は曲げ内力係数、口印は最大内力係数の実験值であ る.図 9 より板厚の減少とともに内力係数および最大 内力係数は減少し，曲げ内力係数は増加少ることがわ かる。また同一板厚の場合 $l_{k 1}$ が大きいほうが内力係 数抢よび最大内力係数が小さく，曲げ内力係数が大き くなる。すなわち，はりがたわみやすいほど内力係数， 最大内力係数は減少し, 曲げ内力係数は増加すること がわかる。また闭理論值と実験值はかなり一致してい ると言える。

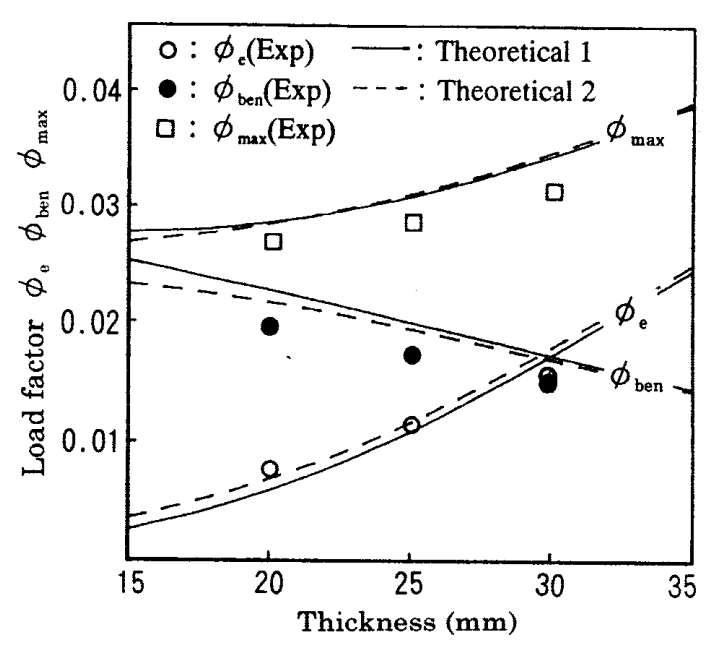

(a) $l_{\mathrm{k} 1}=60 \mathrm{~mm}$

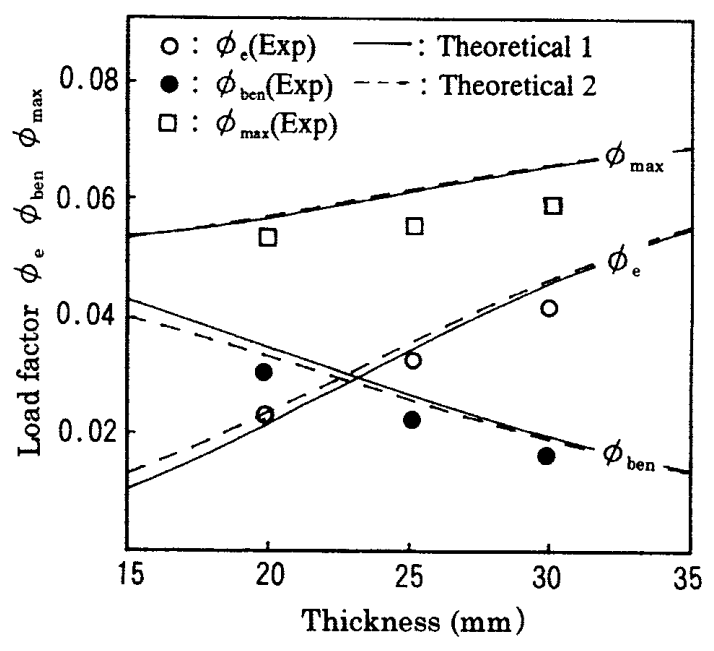

(b) $\quad l_{\mathrm{h} 1}-30 \mathrm{~mm}$

Fig. 9 Comparisons of theoretical values and experimental values of force ratio 


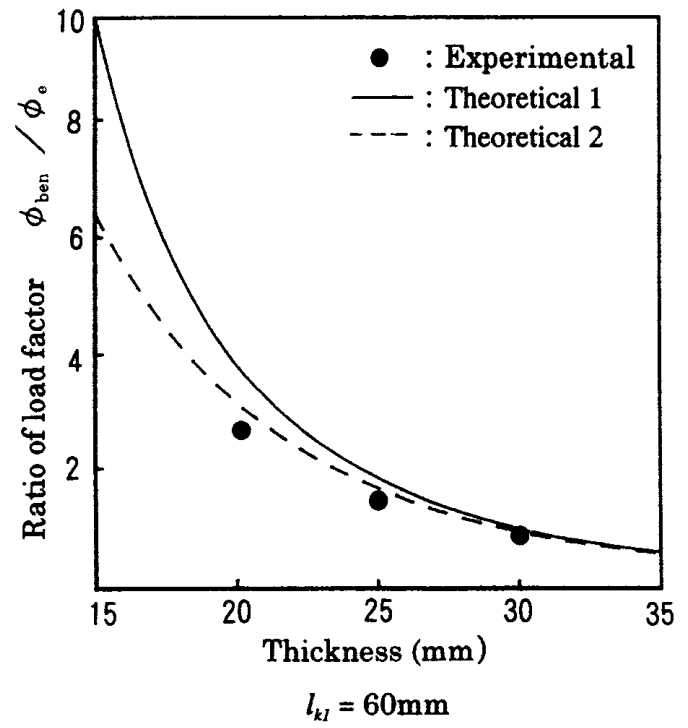

Fig. 10 Comparison between theoretical values and experimental values of $\left(\phi_{b e n} / \phi_{e}\right)$

ここで, 最大内力係数の值では理論値 1,2 間に差が ないが,これは $\phi_{e}, \phi_{\text {ben }}$ で生じている差が相殺されて いるためであり, $\phi_{b e n} / \phi_{e}$ で比べると板厚の小さい範

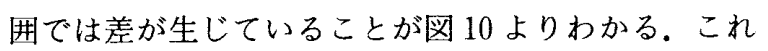
より曲げ内力係数と内力係数の比で比べると理論值 2 が理論值 1 に比べて実験値に近い値を示している. 以 上のことから，剛性の大きいはりでは両理論值に大き な差はなく, 両理論式とも有効であると言える。一方 両理論值に差が生ずる剛性の小さいはりでは締結体の 機能を満たさないことも考えられるが，実際にはどの 程度の剛性で締結体の機能を満たさなくなるのか不明 であることから，剛性の大小を問わず理論 2 を用いた ほうがより安全と言える。

$4 \cdot 2$ ボルトに生ずる曲げモーメントの比較 図 7 (a)の理論值 1,2 では板厚が小さくなると曲げモー メントに大きな差が生じているのに, 図 9 の曲げ内力 係数の両理論值には大きな差が見られない.この理由 は, 図 7 ではボルトの断面形状を正方形としたため, ボルトに対するはりの剛性比が円形断面ボルトのそれ より小さくなり，したがって同一軸力では，曲げモー メントは大きくなるためである。すなわち理論値 1,2 の追加曲げモーメントを $M_{a b}(1), M_{a b}(2)$ とおき, 式 (12)，(13)より同一軸力に対する両モーメントの比 $R_{m}$ を求めると

$$
\frac{M_{a b}(1)}{M_{a b}(2)}=\left[\frac{E_{b}}{12 E_{k} I_{k}} \cdot \frac{\left(l_{k 2}^{2}+6 l_{k 1}^{2}+6 l_{k 1} \cdot l_{k 2}\right)}{\left\{l_{b 1} / I_{b 1}+l_{b 2} /\left(2 I_{b 2}\right)\right\}}\right] / l_{g}
$$

$$
\equiv R_{m}
$$

そこで一例として図 7(a) および図 9(a)の板厚 20 $\mathrm{mm}$ に対する $R_{m}$ を求めてみる. 図 7 では $R_{m}=1.6$, 図 9 では $R_{m}=1.3$ となり同一軸力では図 7 の曲げモ ーメントの比のほうが大きいことがわかる。また理論 1,2 における内力係数を $\phi_{e}(1), \phi_{e}(2)$, 曲げ内力係数 を $\phi_{\text {ben }}(1), \phi_{\text {ben }}(2)$ とおくと, 式(2)，(3)，(12), (13), (21)より

$$
\frac{\phi_{\text {ben }}(1)}{\phi_{b e n}(2)}=\frac{\phi_{e}(1)}{\phi_{e}(2)} \cdot R_{m}
$$

となる.ここで図 9 (a)の板厚 $20 \mathrm{~mm}$ では $\phi_{e}(1) /$ $\phi_{e}(2)=0.87$ となるから $R_{m}=1.3$ であっても $\phi_{\text {ben }}(1) /$ $\phi_{\text {ben }}(2)=1.13$ となり, あまり差が生じないことにな る.

\section{5. 結言}

はり(かんざし)を用いた締結体について現物を縮小 したモデルを作成し実験を行い，はりの剛性が各種内 力係数に及ほす影響を調べた。また，従来フランジ締 結体の解析に用いられている手法, およびこれを一部 修正した手法を用いて各種内力係数を求めるための簡 便な式を導出し，実験結果との比較を行った，得られ た知見は以下のと扔りである。

（1）はりの剛性の低下に伴い内力係数と曲げ内力 係数の和である最大内力係数は減少する.

（2）はりの剛性の低下に伴い内力係数は減少し， 逆に曲げ内力係数は増加する。

（3）修正した手法による理論值は実験値とよく一 致したことから，この手法による理論式は有効である と言える。

最後に本研究を遂行するにあたり，貴重なご助言を いただいた千葉工業大学の江藤元大教授，(株)吉永機 械の池永憲章氏，毛内司氏，また本研究に積極的に協 力いただいた当時千葉工業大学大学院生の木下俊夫 君, 根本渟一君並びに塚越理陽君に感謝の意を表す。

\section{文献}

（1）例之ば，沢俊行・丸山一男，機諭，44-383(1978)，25162527.

（2）例えば，澋俊行，日本好じ研究協会誌，24-2(1993)，36-44

（3）例之ば，睪俊行，日本权じ研究協会誌，24-3(1993)，7078.

（4）例元ば, VDI 2230，(1977)，高強度权じ結合の体系的計算 方法，(1982），日本权じ研究協会。

（5）山本晃，极じ締結の理論と計算，(1970)，61，荃賢堂. 